\title{
Conservation Status of the Argentine Boa Constrictor (Boa constrictor occidentalis) 20 Years After Being Listed in CITES Appendix I
}

Tomás Waller, Patricio A. Micucci, Mariano Barros, Juan Draque, and Candelaria Estavillo

Fundación Biodiversidad-Argentina, Juncal 754, $7^{\text {th }}$ Floor Apt. 60, 1060 Buenos Aires, Argentina (twaller@fibertel.com.ar)

$\mathrm{T}$ wenty years after the species was listed in CITES Appendix I, we carried out a comprehensive review of the conservation status of the Argentine Boa Constrictor (Boa constrictor occidentalis) in Argentina. We compiled background information on trade, biology, and distribution. We evaluated the historical range on the basis of museum and literature records, and later adjusted it to incorporate environmental variables. We carried out 573 interviews with local residents regarding the historical presence of the species and the ways in which it was used. Using a rapid assessment of woody vegetation cover, we estimated the degree of habitat loss in Argentina. We conclude that CITES has been very effective in stopping the international trade and almost completely eliminating hunting pressure on this snake throughout Argentina. However, suitable boa habitat has been reduced by one third to approximately 30 million ha from a historical extent of occurrence of about 42 million ha in the Dry Chaco ecoregion. Loss of suitable habitat is mainly due to recent expansion in agricultural and livestock production. This subspecies is still common throughout its range; how-

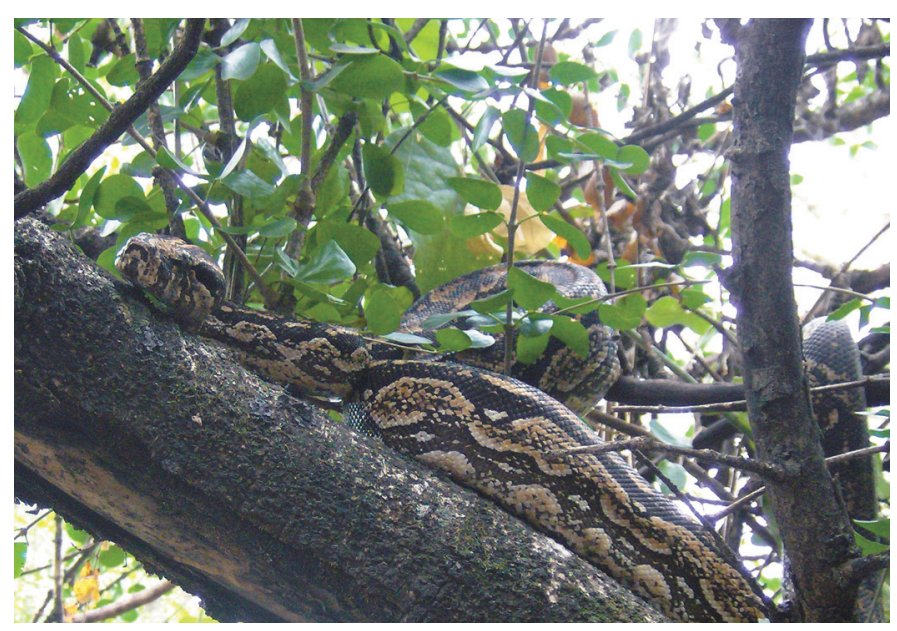

During the winter, boas usually are found perching in the low branches of shrubs near mammal burrows; Fortín Soledad, Province of Formosa. Photograph by Mariano Barros. ever, recent trends in habitat loss led us to conclude that the Argentine Boa Constrictor meets at least one of the CITES criteria for retention in Appendix I, at least until the recently enacted forest protection law proves its effectiveness in protecting the remaining Chaco forests of Argentina.

Boa constrictor is the most widely distributed boid in the Americas, where it occupies plains, foothills, and intermontane valleys from northern Mexico to central Argentina, including numerous coastal islands in the Caribbean Sea and Pacific Ocean. Within this area, it occurs in all countries except Chile and Uruguay. The species' range extends across 66 degrees of latitude, 22 vegetation zones, and 11 morphoclimatic domains, making it first in terms of ecological plasticity in comparison to other boids and in relation to the majority of American species of snakes (Waller and Micucci 1993, Henderson et al. 1995).

The taxonomy of Boa constrictor is problematic. Around fourteen subspecies have been described to date, mostly on the basis of weak diagnostic characters (Peters and Orejas-Miranda

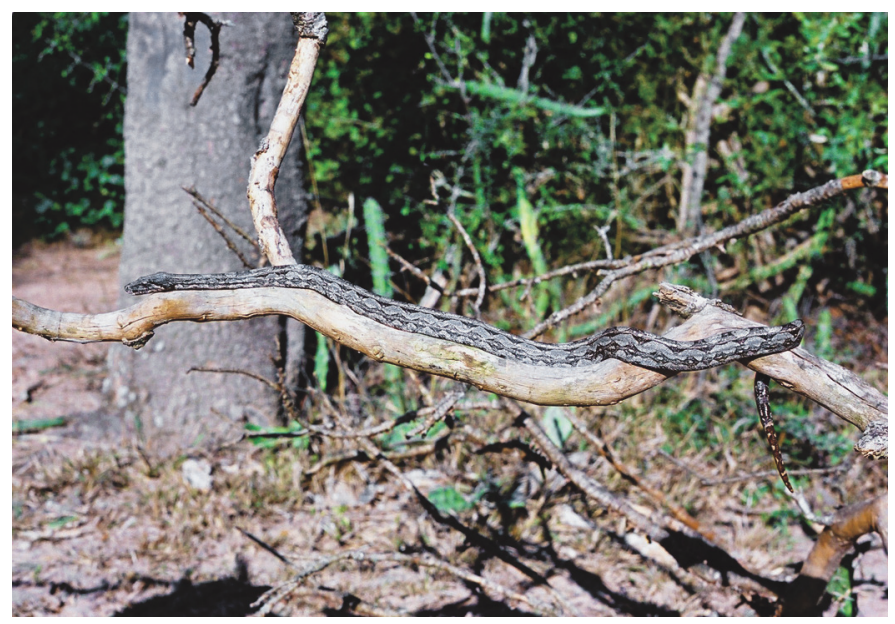

Young individuals of the Argentine Boa Constrictor usually exhibit dots on their backs that are paler than those of adults — and sometimes even pink. Photograph by Tomás Waller. 


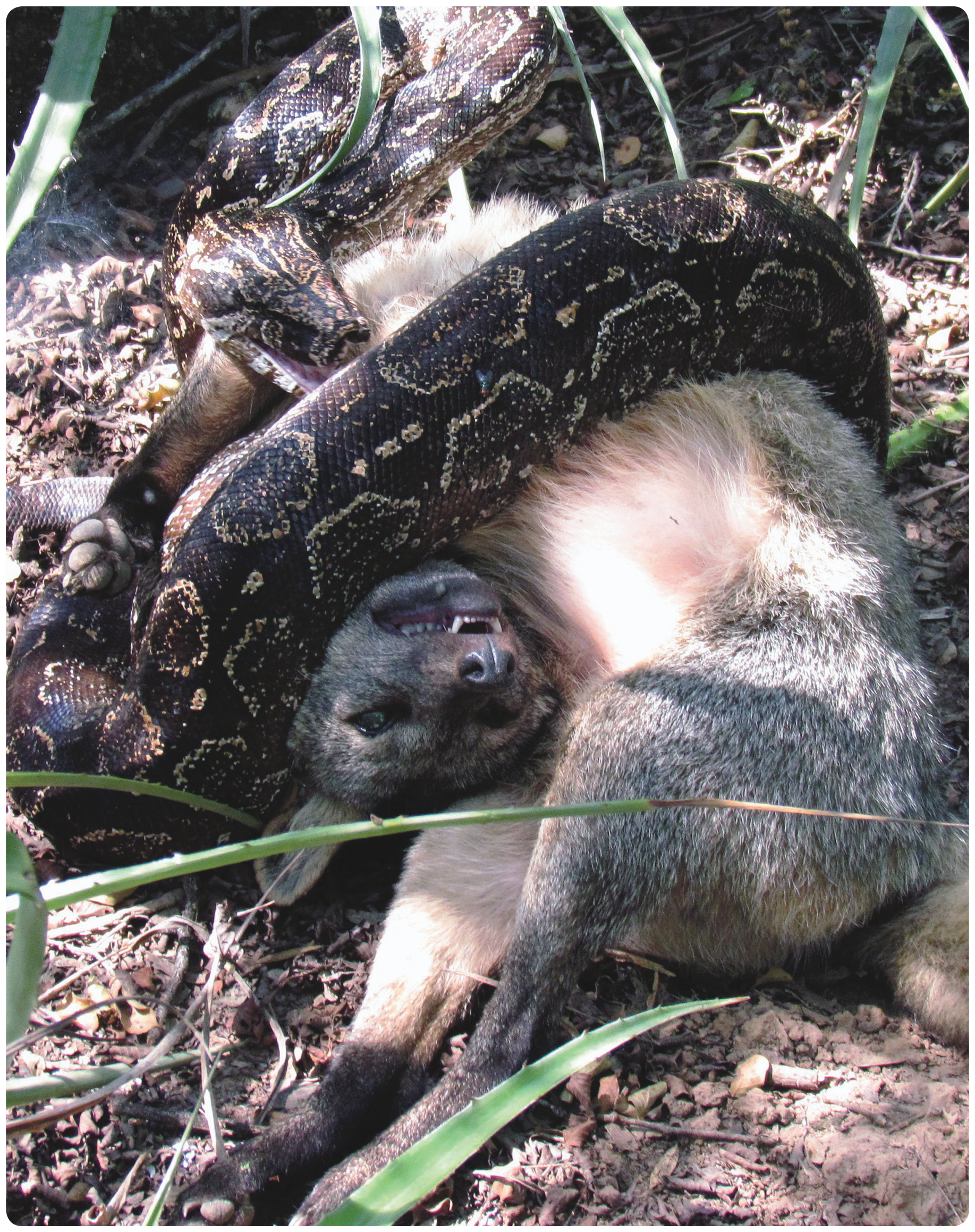

An adult female Argentine Boa Constrictor (Boa constrictor occidentalis) subduing a Crab-eating Fox (Cerdocyon thous), Province of Salta, Argentina. Photograph by Hugo Hulsberg. 


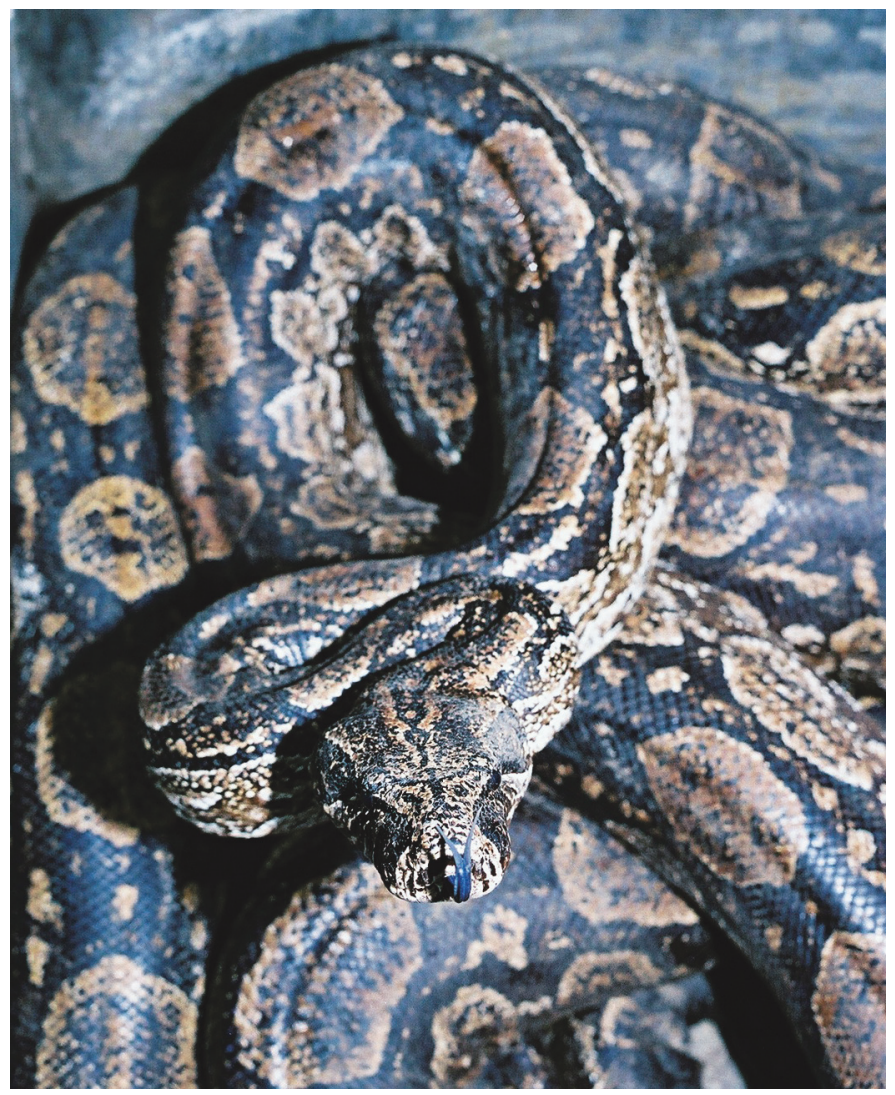

The Argentine Boa Constrictor (Boa constrictor occidentalis) can attain total lengths to $3 \mathrm{~m}$ and masses to $18 \mathrm{~kg}$; Guadalcazar, Province of Formosa. Photograph by Tomás Waller.

1970, 1986; Langhammer 1983; Price and Russo 1991); only eight or nine of the subspecies are consistently recognized, and some authors have suggested these be considered full species (i.e., Boa nebulosa and B. orophias, Price and Russo 1991, Binder and Lamp 2007, Bonny 2007, Daniells et al. 2008, Henderson and Powell 2009). Hynková et al. (2009), using mitochondrial DNA to discern the phylogenetic relationships

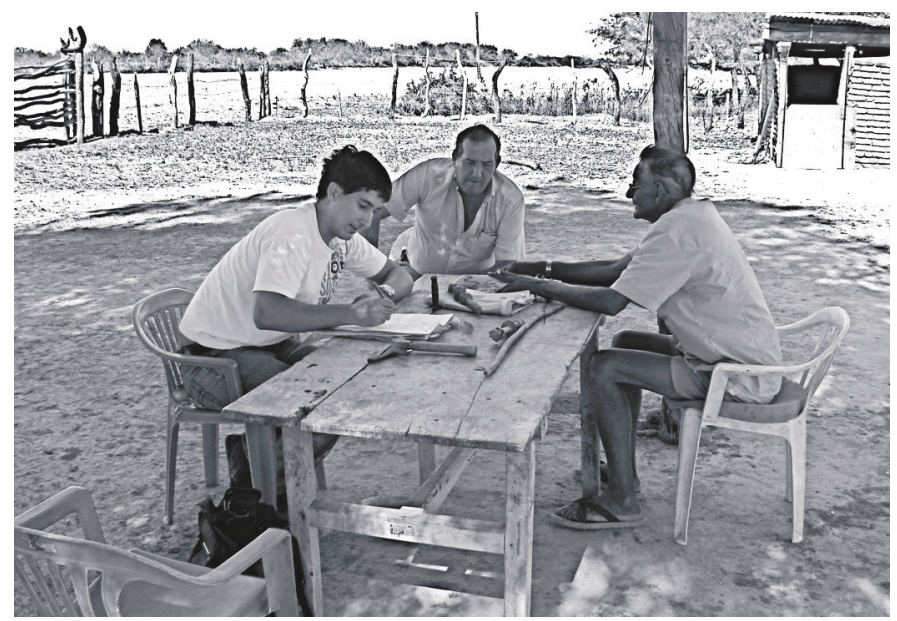

We surveyed about 600 rural inhabitants throughout the boa's range in Argentina to evaluate presence or absence and local uses. Photograph by Juan Draque. among six continental subspecies, suggested that two distinct clades existed, and proposed a division into at least two additional species, Boa constrictor from mainland South America east of the Andes and Boa imperator to the north and west of the Colombian Andes through Central America and México. Their conclusions, however, must be considered tentative, since they were based solely on a partial mitochondrial gene obtained mostly from captive animals.

The Argentine Boa Constrictor (Boa constrictor occidentalis) represents the southernmost taxon in this complex, inhabiting the Great Chaco region from Paraguay to central Argentina and presumably Bolivia (Waller et al. 1995, Di Cola et al. 2008). Chébez et al. (2008) suggested that, due to morphology, distribution, and ecology, this subspecies should be re-elevated to full species status as originally described (Philippi 1873). This subspecies did exhibit the most distinct haplotype within the South American Boa constrictor clade in the study by Hynková et al. (2009).

With a maximum size of about $3 \mathrm{~m}$ in total length, the Argentine Boa Constrictor is undoubtedly the most conspicuous terrestrial snake in Argentina. It is present in the culture of the local human communities that share its habitat. Traditionally hunted by local inhabitants for its fat, to which medicinal properties are attributed (Bolkovic 1999), it also has been exploited on a large scale due to the high value of its skin, which is used in manufacturing fine leather goods (Gruss and Waller 1988).

In 1987, at the Sixth Meeting of the Conference of the Parties to the Convention on International Trade in Endangered Species of Wild Fauna and Flora (CITES) (Ottawa, Canada), B. c. occidentalis was listed in Appendix I of this Convention. As a result of this listing, commercial international trade was banned.

After 20 years of CITES Appendix I listing, Fundación Biodiversidad-Argentina, under the supervision of the

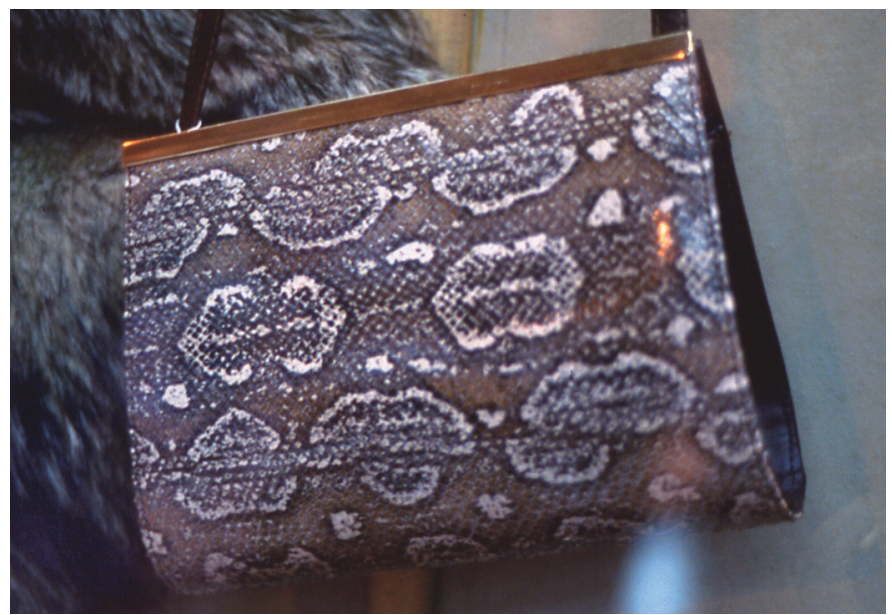

An old "1980s" Boa constrictor occidentalis bag. The fashion industry is no longer the main threat to Argentine Boa Constrictors. Photograph by Tomás Waller. 


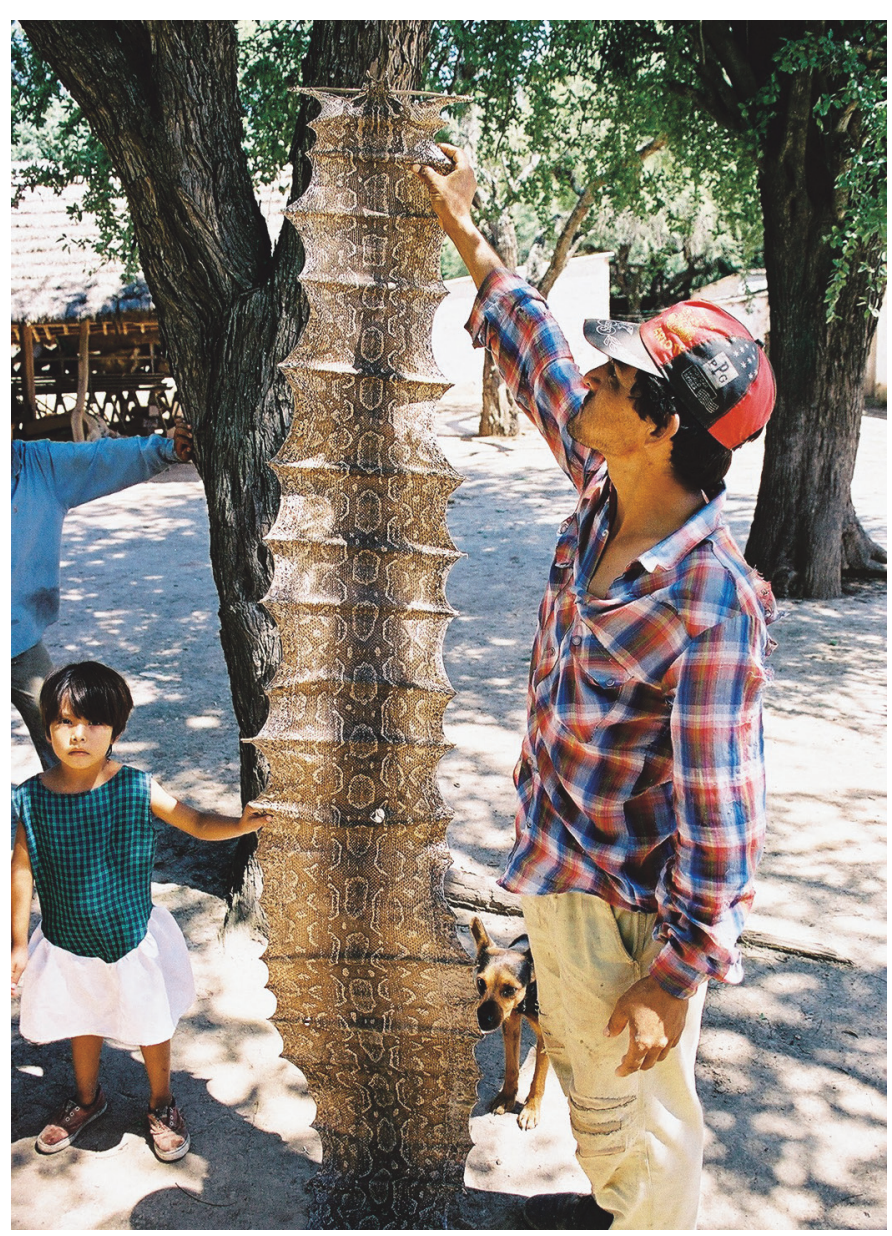

Argentine Boas were a source of income to poor rural inhabitants before the international skin trade was completely stopped by CITES Appendix I listing in 1987. Photograph by Tomás Waller.

CITES Secretariat and the CITES Management Authority of Argentina, conducted a full assessment of incidental trade, current range, and habitat trends, to determine the conservation status of B. c. occidentalis in the country. Here we summarize the most important results included in the full report to the CITES Secretariat (Waller et al. 2010).

\section{Methods}

The survey initially involved a compilation of background information on specific and general references to the Argentine Boa Constrictor and its habitat, the international trade in skins and live specimens recorded in the WCMC/ UNEP CITES Trade Data Base, and a review of available information from various herpetological collections.

Subsequently, we initiated a detailed analysis of historical records relating to environmental and landscape variables aimed at proposing an area of distribution or historic range based on natural boundaries. Using extensive field surveys, we proceeded to test and adjust the distribution map. The field activities, carried out during a period of one-and-a-half years, included nearly 600 interviews with rural inhabitants to check for the historical presence (or absence) of the Argentine Boa throughout its entire range in the country, obtaining information on its habitat, and assessing the value of this snake to rural communities.

In order to evaluate habitat trends, we estimated the loss of woody plant cover in the species' distribution. Taking into account the area and the fine scale needed, we based our analysis on Terra Satellite coverage published online by the NASA Rapid Response System (http://lance.nasa.gov/imagery/rapid-response/). These automatic mosaics reflect satisfactorily the natural discontinuities in woody cover and the anthropogenic transformation of crop and pasture land, with the advantage of being updated on a daily basis. The aim was not to generate a detailed vegetation map, but instead to roughly estimate the loss of continuity in the natural vegetation within the boa's historical range throughout Argentina.

\section{Trade and Other Uses}

According to our review of CITES trade statistics, Boa constrictor (sensu lato) is the snake species in the Americas that has contributed most to global trade, involving both live specimens and skins. About 393,000 skins and 630,000 live specimens of this species were traded in the 29-year span between 1980 and 2008. Commercial trade in skins, mainly to meet the demand from the United States and Italy, soared to tens of thousands of skins per year, particularly over the first decade analyzed (1980-1989). However, following the Appendix I listing of the subspecies B. c. occidentalis in 1987, international trade rapidly decreased to such an extent that reported trade in B. constrictor (sensu lato) skins from 1990 onward represented less than $1 \%$ of the total trade compiled in the CITES database for the entire period (1980-2008; Fig. 1).

Most of the skins reported as B. constrictor (sensu lato) in CITES trade statistics originated in Argentina, probably as a result of lax CITES enforcement in the country at that

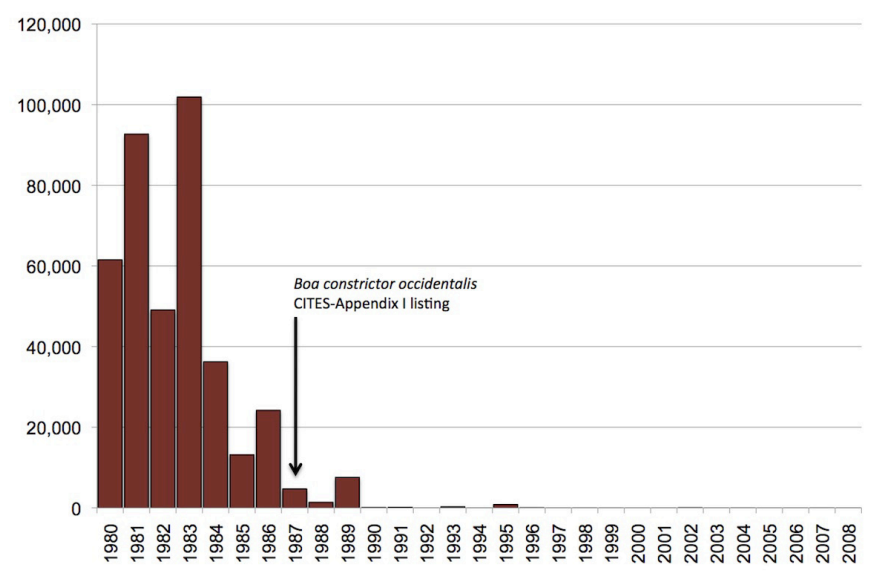

Fig. 1. World net trade in whole skins of Boa constrictor (sensu lato) between 1980 and 2008. Commercial trade diminished almost completely after the listing of B. c. occidentalis in CITES Appendix I (Source: CITES Trade Data Base). 
time, and in Paraguay, which was a source of documentation of dubious legality during the 1980s (Waller and Micucci 1993). That B. c. occidentalis was the main subspecies in the trade should not be surprising, especially since the local media already expressed its concerns very early in the previous century about the potential impact of the snakeskin trade, demonstrating that a commercial network for the subspecies was well established in Argentina as early as the 1940s (Berst 1944, 1947; Llanos and Crespo 1952; Freiberg 1954, 1980; Godoy 1963; Astort 1984; Gruss and Waller 1986, 1988; Waller 1987a, 1992).

On the other hand, CITES statistics show that Argentina did not play a significant role in the international trade of live specimens, with only 1,612 individuals exported in 29 years (1980-2008) compared to the 637,922 snakes exported from Central American countries and, more recently, Colombia during the same time span (Fig. 2).

According to responses to our inquiries during the field surveys, the Argentine Boa Constrictor has no commercial value throughout most of its range. Certainly, CITES has been very effective in reducing and almost completely eliminating hunting pressure on these snakes in Argentina and, very likely,

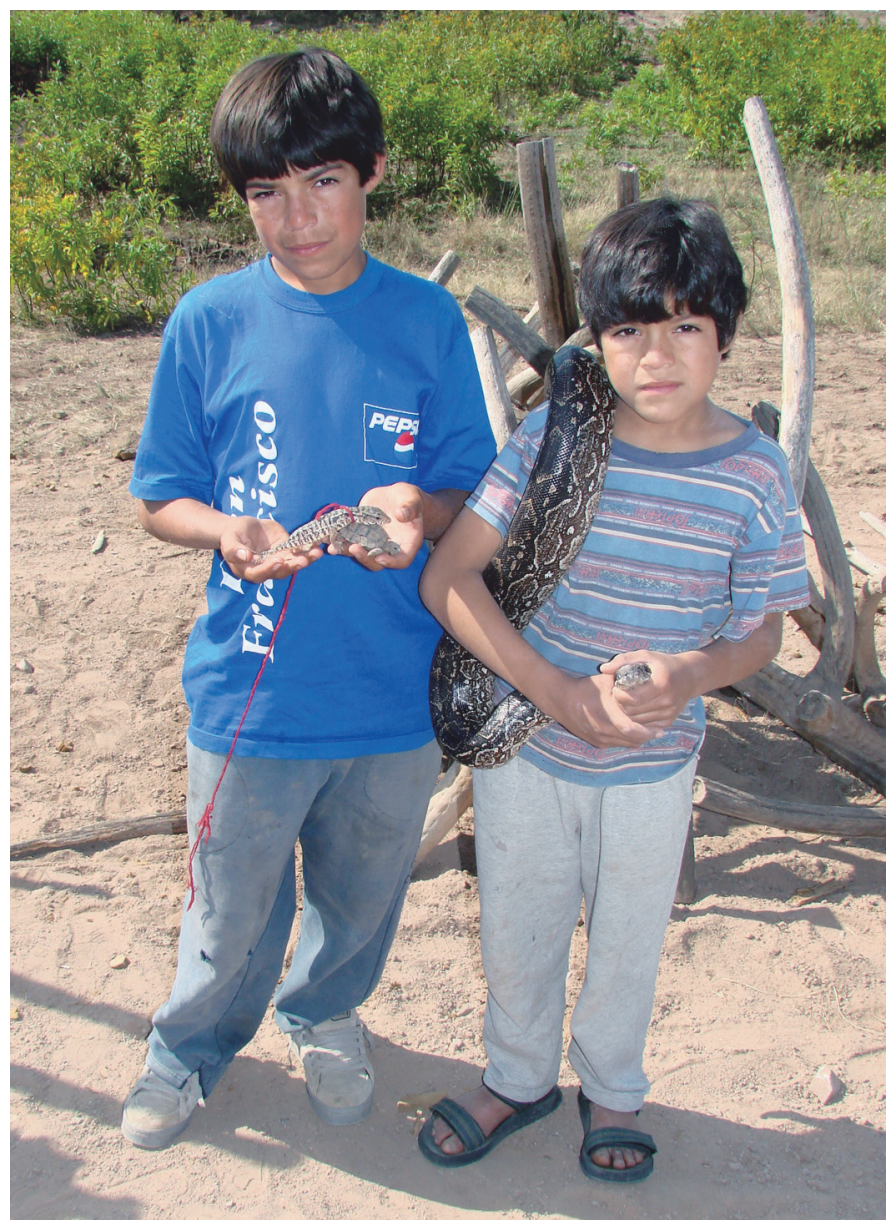

Argentine Boas, Tegu lizards (Tupinambis rufescens), and Chaco Tortoises (Chelonoidis petersi) are usually offered for sale along major roads in central Argentina. Photograph by Tomás Waller.

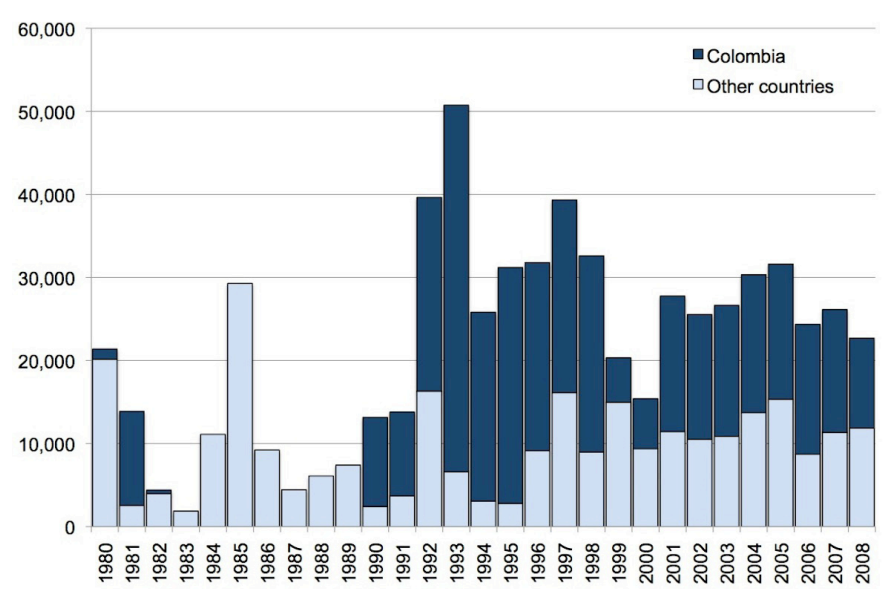

Fig. 2. World net trade in live specimens of Boa constrictor (sensu lato) between 1980 and 2008. Most of the trade involves B. c. imperator from Central American countries and Colombia (Source: CITES Trade Data Base).

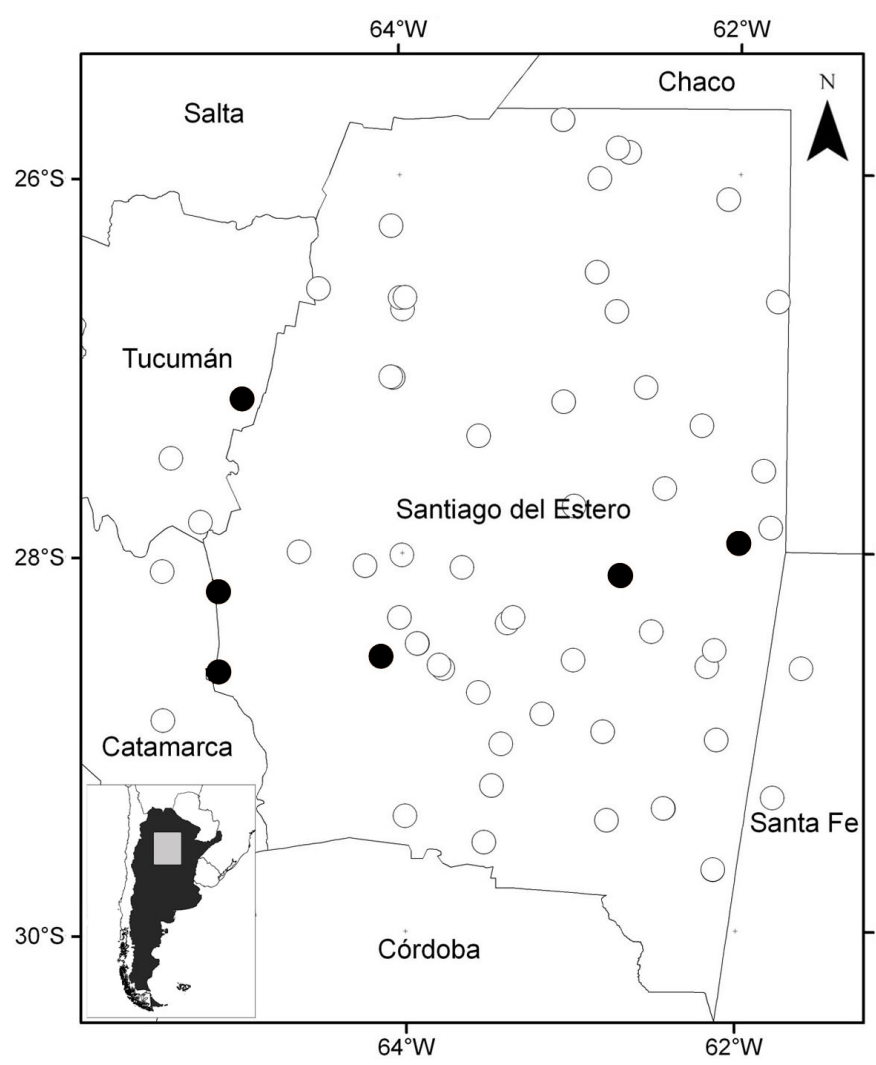

Fig. 3. Localities in central Argentina where inhabitants reported no commercial hunting of Boa constrictor occidentalis for skins (open dots), and localities where inhabitants reported occasional hunting for skins (black dots). Villagers in all the localities visited acknowledged having hunted boas in the past.

in the rest of its range. An occasional and small-scale level of utilization remains in some localities, based on the use of its fat as a traditional medicine and because of the existence of an illegal but rudimentary internal market for skins and live animals (Fig. 3). Skins are sold along routes in the central 
Province of Santiago del Estero as souvenirs for tourists and to supply a small local demand for leather goods in some cities. Live snakes are occasionally sold illegally at public fairs and in pet stores in big cities like Buenos Aires. Despite occasional efforts at smuggling on a larger scale (e.g., www.news.com.au/ travel/news/snakes-on-a-bus-argentina-nabs-wildlife-trafficker/ story-e6frfq80-1226036739802), we consider that none of these activities represent a significant risk to the survival of the species in Argentina.

\section{Historical Range and Habitat Trends}

As a result of our review, the presence of $B$. c. occidentalis was confirmed in 13 of the 23 provinces of Argentina. Furthermore, we estimated that the species' historical extent of occurrence (sensu IUCN 2001) covered approximately 42.3 million ha, equivalent to $15 \%$ of the country's mainland territory (Fig. 4). Boa constrictor reaches its southernmost limit of distribution on the continent at $33^{\circ} 20^{\prime} \mathrm{S}$ latitude in the province of San Luis, Argentina.

The Argentine Boa Constrictor almost exclusively inhabits woody areas of what is known as the Dry Chaco region (Chaco Seco according to Burkart et al. 1999) to an altitude of approximately $900-1,000 \mathrm{~m}$ above sea level, and in zones with yearly seasonal rainfall (spring to summer) of 250-900 $\mathrm{mm}$. It is absent or very rare at higher elevations $(>1,000 \mathrm{~m})$ or in areas with annual rainfall in excess of $900 \mathrm{~mm}$ (i.e., Yungas rainforest), winter flooding (i.e., Humid Chaco), or where soil constraints (salt marshes, rocky outcrops, water bodies) interrupt typical Dry Chaco forest physiognomy.

This boa shows a remarkable ecological plasticity that manifests itself in its ability to live in 20 of 22 terrestrial ecosystem complexes (sensu TNC et al. 2005) within the Dry Chaco. Not surprisingly, boas are able to persist in degraded environments, provided that the area maintains the presence of woody plants and scattered trees with a minimum threshold of heterogeneity to meet their needs for shelter and food (Waller et al. 2010). However, the Argentine Boa Constrictor cannot occupy grass- or crop-dominated cultural landscapes unless the habitat is part of a more complex spatial matrix that includes patches of typical woody vegetation. In effect, today's main threat for this subspecies is no longer exploitation for food, hides, or pets, but habitat loss and fragmentation - the shrinkage of its range as a result of land use changes to agriculture and livestock rearing.

Local effects of habitat fragmentation have been the focus of recent research in the Province of Córdoba in central Argentina. Although no evidence of inbreeding or significant levels of genetic differentiation were found in two boa populations studied in fragmented habitats, this was attributed to the relatively recent history of habitat conversion in the area (Rivera et al. 2005, 2006). Furthermore, Rivera et al. (2006)

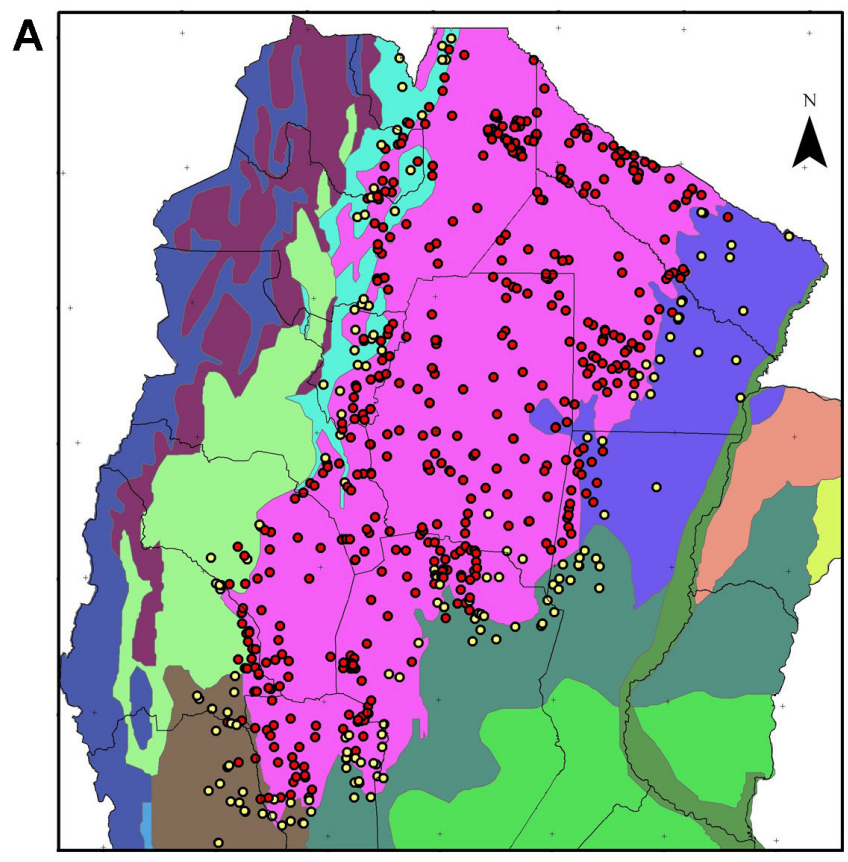

Dry Chaco

Wet Chaco

Espinal Savannas

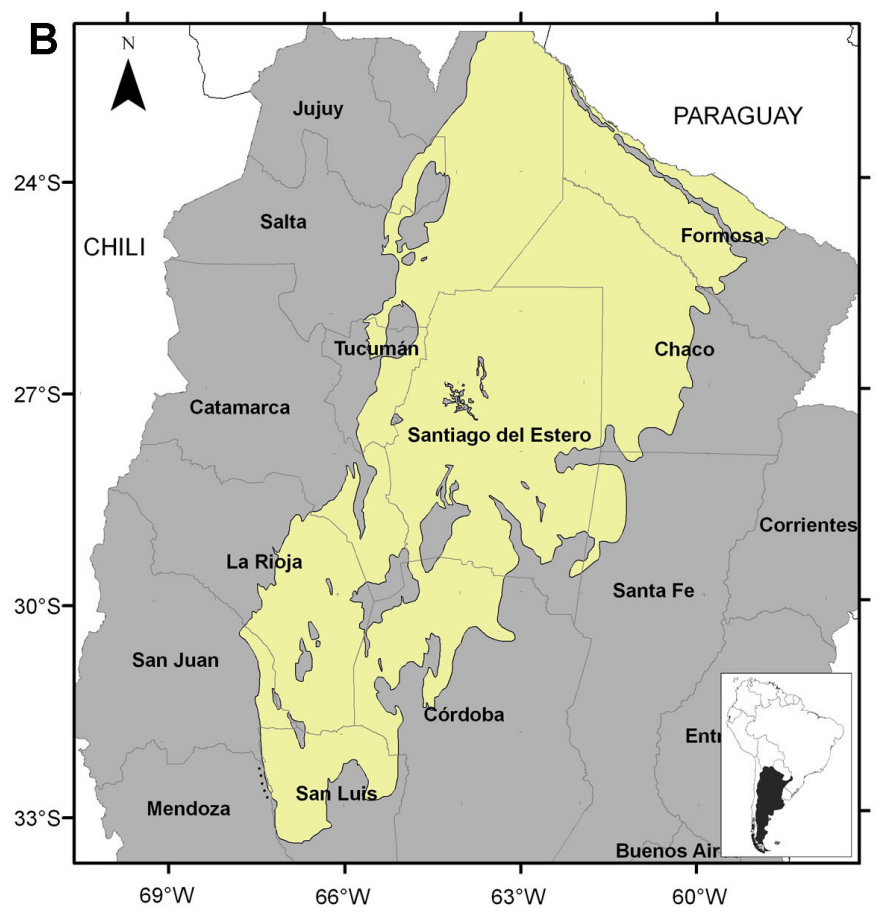

Fig. 4. (A) Presence records (red dots) versus absence records (yellow dots) in relation to major habitat types in Argentina (Burkart et al. 1999). Records obtained from museum collections, literature, and reliable interviews show that Boa constrictor occidentalis occurs almost exclusively throughout the woodlands of what is known as the Dry Chaco region to elevations of 1,000 $\mathrm{m}$ above sea level (asl). (B) The estimated extent of occurrence (sensu IUCN 2001) of B. c. occidentalis in Argentina after excluding major woodland discontinuities (i.e., salt marshes, river floodplains, and elevations above 1,000 $\mathrm{m}$ asl) covers about 42 million ha within the Dry Chaco region. 
found a high degree of gene flow among studied populations, which they attributed to the high dispersal capability of males. However, a subsequently detected decrease in gene flow (Cardozo et al. 2007) could be the result of a progressive increase in habitat isolation. Strong differences in important life history traits (e.g., size, body condition, and reproductive output) in relation to habitat complexity have also been observed, and the long-term viability of boa populations at these locations is a matter of concern and the subject of ongoing research (e.g., Cardozo and Chiaraviglio 2008, 2011).

According to our study, the clearing and replacement of forests and shrublands by crops and land for livestock rearing is responsible for a $29 \%$ decrease in the historical range of $B$. c. occidentalis in Argentina. Its current potential occupation area covers 30.2 million ha, some 12 million ha less than its historical potential (Table 1). Twenty percent of the identified habitat contraction is the result of changes in land use that occurred during the past decade. In absolute terms, the largest habitat loss took place in the provinces of Santiago del Estero, Salta, Chaco, and Córdoba, in which over 9 million ha of forests and shrublands were cleared. However, in relative terms, the most affected provinces were Tucumán and Santa $\mathrm{Fe}$, since both have lost over $70 \%$ of the original habitat of this subspecies. The process, however, basically followed a centripetal pattern, which enhances the likelihood that large fragments of habitat will persist (Table 2). These provide for a continuous landscape in $90 \%$ of the remaining territory in the form of a large column of suitable habitat from the northern limit of the snake's distribution in the province of Formosa, to its southernmost limit in the province of San Luis - with the notable exception of the provinces of Tucumán and Santa

Table 1. Original habitat size and extent of habitat loss for Boa constrictor occidentalis in Argentina.

\begin{tabular}{lcrrr} 
Province & $\begin{array}{c}\text { Original } \\
\text { Habitat (ha) }\end{array}$ & $\begin{array}{c}\text { Current } \\
\text { Habitat (ha) }\end{array}$ & $\begin{array}{c}\text { Habitat } \\
\text { Loss (ha) }\end{array}$ & $\begin{array}{r}\text { Habitat } \\
\text { Loss (\%) }\end{array}$ \\
\hline Santiago del Estero & $11,885,047$ & $7,604,468$ & $4,280,579$ & 35.4 \\
\hline Salta & $6,921,872$ & $5,045,602$ & $1,876,270$ & 15.5 \\
\hline Chaco & $6,206,342$ & $4,419,698$ & $1,786,644$ & 14.8 \\
\hline Formosa & $3,956,459$ & $3,651,826$ & 304,633 & 2.5 \\
\hline La Rioja & $3,987,672$ & $3,607,618$ & 380,054 & 3.1 \\
\hline Córdoba & $3,229,838$ & $1,945,404$ & $1,284,434$ & 10.6 \\
\hline San Luis & $2,284,646$ & $1,923,426$ & 361,220 & 3.0 \\
\hline Catamarca & $1,369,510$ & 981,754 & 387,757 & 3.2 \\
\hline Tucumán & $1,039,506$ & 287,853 & 751,653 & 6.2 \\
\hline Santa Fe & $\mathbf{6 9 3 , 7 8 1}$ & 174,375 & 519,407 & 4.3 \\
\hline Jujuy & 404,975 & 265,637 & 139,337 & 1.2 \\
\hline San Juan & 318,897 & 309,369 & 9,528 & 0.1 \\
\hline Mendoza & Occasional & Occasional & - & - \\
\hline Extent of occurrence & $\mathbf{4 2 , 2 9 8 , 5 4 5}$ & $\mathbf{3 0 , 2 1 7 , 0 3 0}$ & $\mathbf{1 2 , 0 8 1 , 5 1 6}$ & $\mathbf{2 8 . 6}$
\end{tabular}

Table 2. Degree of fragmentation of the habitat of Boa constrictor occidentalis in Argentina.

\begin{tabular}{lrrr}
$\begin{array}{l}\text { Habitat Patch } \\
\text { Size }(\mathrm{Ha})\end{array}$ & $\begin{array}{c}\text { Number } \\
\text { of Patches }\end{array}$ & $\begin{array}{c}\text { Total Area of } \\
\text { Patches (ha) }\end{array}$ & $\begin{array}{r}\text { Average Size } \\
\text { of Patches (ha) }\end{array}$ \\
\hline$>1,000,000$ & 3 & $28,205,639$ & $9,401,880$ \\
\hline $100,000-999,999$ & 1 & 102,819 & 102,819 \\
\hline $10,000-99,999$ & 25 & 544,540 & 21,782 \\
\hline $1,000-9,999$ & 281 & 691,254 & 2,460 \\
\hline $100-999$ & 1,950 & 550,416 & 282 \\
\hline T-100 & 11,169 & 235,703 & 21 \\
\hline Total & 13,429 & $30,330,371$ & -
\end{tabular}

$\mathrm{Fe}$, where the isolation of populations now appears to be irreversible (Fig. 5).

Suitable habitat for the Argentina Boa Constrictor in the 18 national and provincial protected areas identified within its range covers barely $1.7 \%$ of its distribution area $(716,824$ ha), with the aggravating factor that most of these areas have little to no effective protection. However, the recent enactment of a National Law for the Protection of Native Forest (Law 26.331) has promoted the development of Land Management Plans (LMP) in most provinces of the species' range. These LMPs establish the areas that should be preserved with their original forest cover and those that may be converted for agricultural use. In a scenario of full compliance with the LMPs prepared by nine of 13 provinces through

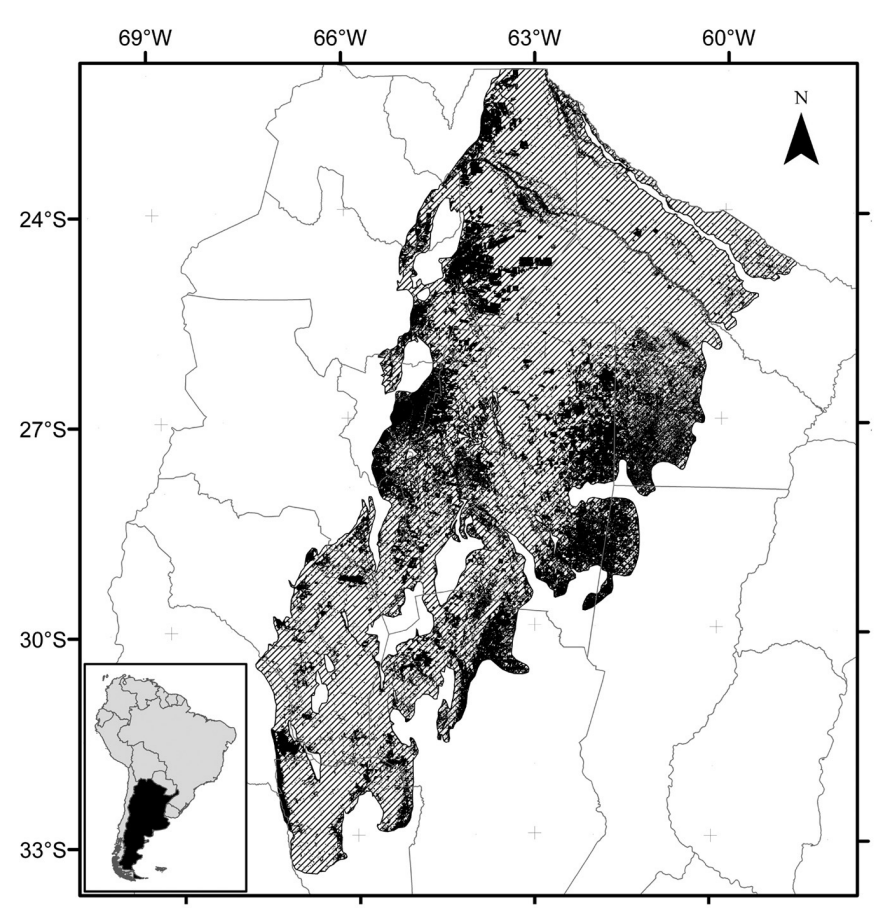

Fig. 5. Boa constrictor occidentalis habitat loss in Argentina (black areas). One-third of what is known as the Dry Chaco forests and shrublands has been converted to crops or to grasslands for livestock production. 
2010, habitat loss could potentially increase from the current value of $29 \%$ of the species' original range in Argentina to a maximum of $46 \%$, which implies that somewhere between 23 to 25 million ha of the original habitat of B. c. occidentalis would ultimately remain.

\section{Abundance}

No scientifically sound references address current or historical population densities for the Argentine Boa Constrictor. However, B. c. occidentalis was described as "very abundant" in the Province of Santiago del Estero during the 1960s (Abalos et al. 1965), and tens of thousands of skins were exported every year for five decades for the leather industry before the trade was banned by CITES in 1987 (Godoy 1963, Gruss and Waller 1988). More recently, some authors (e.g., Kacoliris et al. 2006, Chébez et al. 2008, Waller et al. 2010) have referred to this boa as a common snake in several parts of its range.

Evaluating abundance in such an extensive range was not in the scope of our study; however, during inquires made to
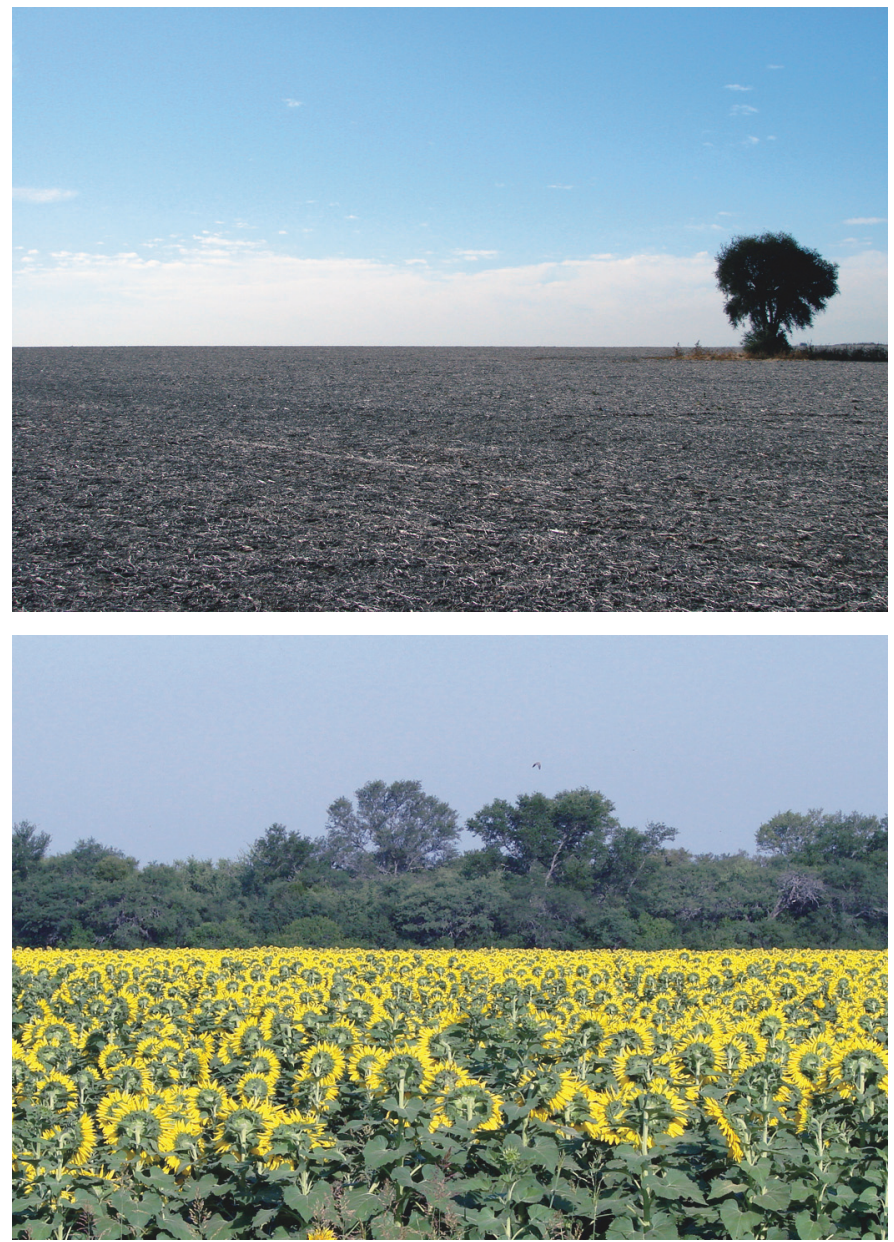

Large-scale deforestation accounts for the loss of one-third of total Boa Constrictor habitat in Argentina (above); however, these snakes are able to persist in cultural landscapes providing a matrix of forest remnants among crops (below). Photographs by Tomás Waller.

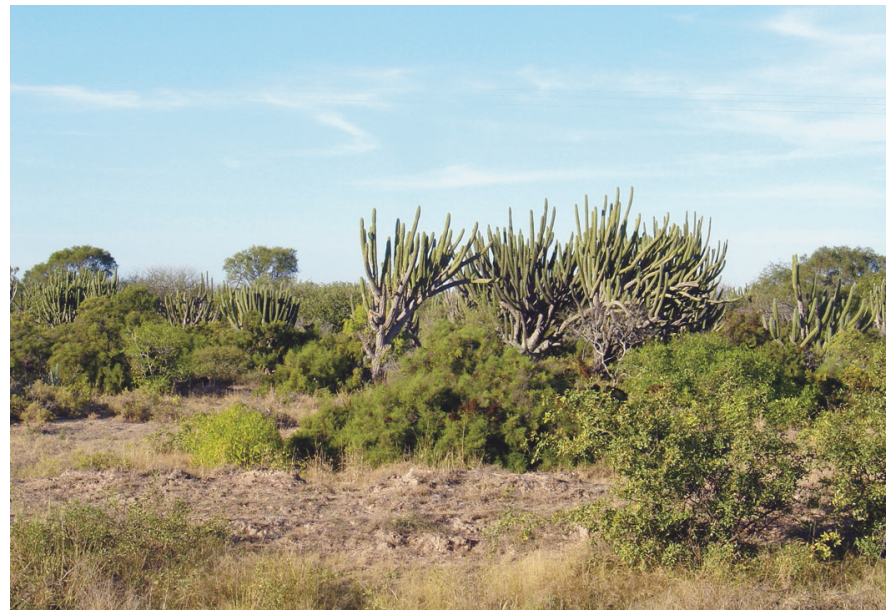

Boa constrictor occidentalis occurs almost exclusively in dry forests and shrublands in what is known as the Chaco region in Argentina, Paraguay, and presumably Bolivia. Photograph by Tomás Waller.

rural inhabitants, we found that the species was repeatedly reported as present throughout most of its distribution area and even in patchy or marginal habitats (i.e., desert-like areas of Mendoza, San Luis, and San Juan provinces and forest relicts in the eastern regions of Córdoba, Santiago del Estero, Tucumán, and Santa Fe provinces). Moreover, during short surveys in the Province of Formosa, we found these boas can be locally abundant. In Guadalcazar, for instance, we obtained about 30 adult-sized specimens in a short period on two different occasions (2003 and 2007). All were captured by local inhabitants in the immediate surroundings of this small village, when crossing dirty roads, or when basking near the dens of a large rodent, the Plains Viscacha (Lagostomus maximus, Chinchillidae), located alongside an abandoned airstrip.

\section{National and International Conservation Measures}

Aside from the ban on commercial international trade imposed by the CITES Appendix I listing, no specific conservation actions have been undertaken for this species in Argentina - with the exception of a prohibition on hunting and trade, both at the national and provincial levels. Furthermore, the Argentine Boa Constrictor has not yet been assessed for the Red List by the IUCN, but it is locally considered Threatened under a different categorization scheme by Lavilla et al. (2000).

After a 24-year commercial trade ban as a result of the CITES Appendix I listing, we assessed whether the Argentine Boa Constrictor meets the criteria for such a listing, or if a down-listing to Appendix II would be more appropriate. Annex 4 (Precautionary measures) of resolution Res. Conf. 9.24 (Rev.CoP15) established that "... Species included in Appendix I should only be transferred to Appendix II if they do not satisfy the relevant criteria in Annex $1 . . . "$ and additionally meet a series of precautionary safeguards (Paragraph A.2.). We have analyzed each of the biological criteria established in Annex 1 
of Res. Conf. 9.24 (Rev.CoP15) as they apply to B. c. occidentalis and have reached the following conclusions:

Criterion A: The condition that the population is small is not met. On the one hand, the magnitude of the historical trade of tens of thousands of skins per year, sustained for over five decades, can be interpreted as an indication of the resilience and natural abundance of populations. The size of its current area of distribution in Argentina alone ( $>30$ million ha), its capacity to occupy most of the various Chaco habitats, and its persistence even in ecosystems with a long history of degradation, attest to the existence of a large population throughout its present range.

Criterion B: The condition that the area of distribution is restricted is not met. Its range is still mostly continuous along the Argentinean Dry Chaco (> 30 million ha), reaching also Paraguay (and presumably Bolivia), and the area of distribution probably exceeds a total of 45 million ha in the three countries.

Criterion C: Criterion C. Sub-paragraph ii is met, since it is possible to infer or predict a marked decline in population size in nature, for the following two reasons: (a) A decrease in habitat area close to $30 \%$, at least in Argentina (this survey), and (b) A decrease in habitat quality (and habitat capacity) affecting populations in some areas of its distribution (Cardozo and Chiaraviglio 2008).

The marked decline described in Criterion $\mathrm{C}$ relates primarily to the recent rate of habitat loss, which undoubtedly led to a gradual reduction of the area of occupancy and, consequently, of population size. Yet these factors do not pose a threat of extinction at the regional or even national level, although we envisage future local threat situations in provinces like Santa Fe and Tucumán or in the northeastern sector of Cordoba, for example, where populations are confined to isolated forest patches. Considering the past commercial value of the skin of this subspecies in the international market, an Appendix I listing is justified on a precautionary basis under this situation and the uncertainty about the future of the subspecies' habitat.

\section{Final Remarks}

According to our data, the situation for the Argentine Boa Constrictor in some provinces may warrant actions at that level, but on a broad scale, B. c. occidentalis is not endangered and does not meet the basic conditions for an Action Plan at the national level. Its distribution only in Argentina is still very extensive ( $>30$ million ha) and its situation in relation to land-change patterns does not differ from most species inhabiting the Dry Chaco region. Although no evidence points to an imminent extinction risk or significant trade on a regional or global scale, the skins' historical value and the recent negative habitat trends for $B$. c. occidentalis justify its current CITES Appendix I listing under a precautionary approach.
As a consequence of the enactment (2007) and ruling (2009) of the National Law for the Protection of Native Forests (Law 26.331), a change in current trends of habitat loss is expected. Consequently, we recommended to the CITES Secretariat that the listing of B. c. occidentalis in Appendix I be reviewed again in ten years, taking special account of the advance of deforestation in Argentina and in other countries in the range of this taxon.

Although not feasible in the current situation, the possibility of resuming utilization of this subspecies for the benefit of local communities, under proper management programs, and in those provinces that properly conserve their native forests, should not be discarded. Sustainable use of natural resources present in these ecosystems is one of the few incentives for local communities to conserve them; by depriving them of this option, their opportunities for development are limited and their livelihoods threatened. On the other hand, lack of development opportunities based on utilization of native resources promotes the gradual replacement of natural ecosystems by artificial alternatives, particularly those involving agriculture.

The present situation for the Argentine Boa Constrictor in the provinces of Tucumán, Santa Fe, and eastern Córdoba, where the extent of habitat loss and consequent isolation of populations pose an almost irreversible threat in terms of their viability, is of particular concern. Specific actions should be taken to preserve these populations, possibly using the Argentine Boa as a flagship species to promote the creation of protected areas.

Recent field research has been concentrated in a few localities in Argentina. Considering the wide range of habitats that this subspecies occupies and differences observed in life history traits among, for instance, Córdoba, Santiago del Estero, and Formosa (Waller et al. 2010; Cardozo and Chiaraviglio 2008, 2011), more studies are needed to ensure that interpretations concerning the conservation status of these populations are based on adequate sample sizes and representative observations on appropriate spatial and temporal scales.

Finally, we stress that the best conservation strategy for this snake is to ensure the maintenance of large tracts of forest habitat. In this sense, the conservation of the Argentine Boa Constrictor depends strongly on successful implementation of the various land management plans recently approved in the provinces within its range. These hopefully will ensure habitat conservation for the long term.

\section{Acknowledgements}

This work was made possible by support from the CITES Authorities of Belgium and the CITES Secretariat. We are particularly indebted to Georges Evrard, Victoria Lichtschein, and Obdulio Menghi for promoting this project in its early stages. Guillermo Puccio, Ernesto Alvarenga, Jorge Contreras, 
Federico Rivas, Romina Díaz, Augusto Cuba, Flavio Moschione, Miguel González, and Bettina Aued collaborated during various stages of the project.

\section{Literature Cited}

Abalos, J.W., E.C. Báez, and R. Nader. 1965. Serpientes de Santiago del Estero. Acta Zoologica Lilloana 20:211-283.

Astort, E. 1984. La Boa de las Vizcacheras. Fauna Argentina No 35. Centro Editor de América Latina (CEAL), Buenos Aires.

Berst, A. 1944. Las Boas en la Provincia de Santa Fe. Publicación del Museo de Ciencias Naturales del Colegio de la Inmaculada Concepción de Santa Fe, Argentina.

Berst, A. 1947. Ofidios útiles. Diario El Orden, 19 de octubre. Santa Fe, Argentina.

Binder, S. and A. Lamp. 2007. Boa constrictor. Die Abgottschlange. Natur und Tier Verlag, Münster, Germany.

Bolkovic, M.L. 1999. Usos de fauna silvestre de pobladores de las cercanías de la Reserva Provincial Copo, Santiago del Estero, Argentina, pp. 117-174. In: T.G. Fang, O.L. Montenegro, and R.E. Bodmer (eds.), Manejo y Conservación de Fauna Silvestre en América Latina. Museo Noel K. Mercado, Universidad Autónoma G.R. Moreno, University of Florida, Instituto de Ecología y Wildlife Conservation Society. Editorial Instituto de Ecología. La Paz, Bolivia.

Bonny, K. 2007. Die Gattung Boa. Taxonomie und Fortpflanzung. Kirschner \& Seufer Verlag, Rheinstetten, Germany.

Burkart, R., N.O. Bárbaro, R.O. Sánchez, and D.A. Gómez. 1999. Eco-regiones de la Argentina. Administración de Parques Nacionales, Buenos Aires.

Cardozo, G. and M. Chiaraviglio. 2008. Landscape changes influence the reproductive behaviour of a key 'capital breeder' snake (Boa constrictor occidentalis) in the Gran Chaco region, Argentina. Biological Conservation 141:3050-3058.

Cardozo, G. and M. Chiaraviglio. 2011. Phenotypic plasticity of life history traits in relation to reproductive strategies in Boa constrictor occidentalis. Evolutionary Ecology 25:1163-1177.

Cardozo, G., P.C. Rivera, M. Lamfri, M. Scavuzzo, C. Gardenal, and M. Chiaraviglio. 2007. Effects of habitat loss on the genetic structure of populations of the Argentine Boa Constrictor (Boa constrictor occidentalis), pp. 329-338. In: R.W. Henderson and R. Powell (eds.), Biology of the Boas and Pythons. Eagle Mountain Publishing LC, Eagle Mountain, Utah.

Chébez, J.C., T. Waller, and P.A. Micucci. 2008. Ampalagua, pp. 281-287. In: J.C. Chébez (ed.), Los Que Se Van. Fauna Argentina Amenazada. Tomo 1. Editorial Albatros, Buenos Aires.

Daniells, E.A., J.W. Ackley, R.E. Carter, P.J. Muelleman, S.M. Rudman, P.A. Turk, N.J. Vélez Espinet, L.A. White, and N.N. Wyszynski. 2008. An annotated checklist of the amphibians and reptiles of Dominica, West Indies. Iguana 15:130-141.

Di Cola, V., G. Cardozo, M. Lanfri, M. Scavuzzo, and M. Chiaraviglio. 2008. Modeling the distribution of the boid snakes, Epicrates cenchria alvarezi and Boa constrictor occidentalis in the Gran Chaco (South America). AmphibiaReptilia 29:299-310.

Freiberg, M.A. 1954. Vida de batracios y reptiles sudamericanos. Cesarini Hnos., Buenos Aires.

Freiberg, M.A. 1980. La boa de las vizcacheras. Diario La Prensa, 20 de abril. Buenos Aires.

Godoy, J.C. 1963. Fauna silvestre. Consejo Federal de Inversiones. Evaluación de los recursos naturales de la Argentina. Volumes 1 and 2. Consejo Federal de Inversiones (CFI), Buenos Aires.

Gruss, J.X. and T. Waller. 1986. Resumen del problema de la conservación de la herpetofauna argentina. Amphibia \& Reptilia 1:3-13.

Gruss, J.X. and T. Waller. 1988. Diagnóstico y recomendaciones sobre la administración de recursos silvestres en Argentina: La década reciente (un análisis sobre la administración de la fauna terrestre). CITES-WWF-TRAFFIC Sudamérica, Buenos Aires.
Henderson, R.W. and R. Powell. 2009. Natural History of West Indian Reptiles and Amphibians. University of Florida Press, Gainesville.

Henderson, R.W., T. Waller, P. Micucci, G. Puorto, and R. Bourgeois. 1995. Ecological correlates and patterns in the distribution of Neotropical boines (Serpentes: Boidae): A preliminary assessment. Herpetological Natural History 3(1):15-27.

Hynková, I., Z. Starostová, and D. Frynta. 2009. Mitochondrial DNA variation reveals recent evolution of main Boa constrictor clades. Zoological Science 26:623-631.

Kacoliris, F.P., I. Berkunsky, and J. Williams. 2006. Herpetofauna of the Argentinean impenetrable Great Chaco. Phyllomedusa 5:149-157.

Langhammer, J.K. 1983. A new subspecies of Boa Constrictor, Boa constrictor melanogaster, from Ecuador (Serpentes: Boidae). Tropical Fish Hobbyist 32(4):70-79.

Llanos, A.C. and J.A. Crespo. 1952. Ecología de la Vizcacha (Lagostomus maximus maximus Blainv.) en el nordeste de la provincia de Entre Ríos. Ministerio de Agricultura y Ganadería, Revista de Investigaciones Agricolas 6:289-378.

Peters, J.A. and B.R. Orejas-Miranda. 1986. Catalogue of Neotropical Squamata. Part I. Snakes. Revised edition. Smithsonian Institution Press, Washington, D.C.

Price, R.M. and P.Russo. 1991. Revisionary comments on the genus Boa with the description of a new subspecies of Boa constrictor from Peru. The Snake 23:29-35.

Philippi, R.A. 1873. Über die Boa der westlichen Provinzen der Argentinischen Republik. Zeitschrift für die Gesammten Naturwissenschaften 41:127-130.

Rivera, P.C., M. Chiaraviglio, G. Pérez, and C.N. Gardenal. 2005. Protein polymorphism in populations of Boa constrictor occidentalis (Boidae) from Córdoba Province, Argentina. Amphibia-Reptilia 26:175-181.

Rivera, P.C., C. Gardenal, and M. Chiaraviglio. 2006. Sex biased dispersal and high levels of gene flow among local populations in the Argentine Boa Constrictor, Boa constrictor occidentalis. Austral Ecology 31:948-955.

The Nature Conservancy (TNC), Fundación Vida Silvestre Argentina (FVSA), Fundación para el Desarrollo Sustentable del Chaco (DeSdelChaco) and Wildlife Conservation Society Bolivia (WCS). 2005. Evaluación Ecorregional del Gran Chaco Americano. Fundación Vida Silvestre Argentina, Buenos Aires.

Unión Internacional para la Conservación de la Naturaleza (UICN). 2001. Categorías y criterios de la Lista Roja de la UICN. Versión 3. 1. Preparado por la Comisión de Supervivencia de Especies de la UICN. Unión Mundial para la Naturaleza. Gland, Switzerland.

Waller, T. 1987a. Boa de las vizcacheras: Más que una necesidad, una deuda con la especie. FVSA/RIE/AOP-NotiCITES'87 1(1): 1. Boletín preparado para su distribución durante la VI Reunión de la Conferencia de las Partes en CITES, Ottawa, Canadá.

Waller, T. 1987b. Propuesta de Inclusión de Boa constrictor occidentalis en el Apéndice I de la Convención sobre el Comercio Internacional de Especies Amenazadas de la Fauna y Flora Silvestres (CITES). Documento presentado por la República Oriental del Uruguay en la VI Reunión de la Conferencia de las Partes en CITES, Julio de 1987, Ottawa, Canadá.

Waller, T. 1992. De nuestro libro rojo. Ficha No 26: Boa de las Vizcacheras. Fundación Vida Silvestre Argentina, Revista Vida Silvestre 27:25-26.

Waller, T. and P.A. Micucci. 1993. Estado actual del conocimiento de la biología, comercio y conservación de las boas neotropicales: Géneros Boa L. (1758) y Eunectes Wagler (1830) (Reptilia: Serpentes: Boidae). TRAFFIC Sudamérica y la Secretaría CITES, Buenos Aires.

Waller, T., P.A. Micucci, and E.B. Palumbo. 1995. Distribución y conservación de la familia Boidae en el Paraguay. Autoridad Científica CITES, Secretaría CITES y TRAFFIC Sudamérica, Asunción, Paraguay.

Waller, T., P.A. Micucci, M. Barros, J. Draque, and C. Estavillo. 2010. Conservación de la Boa Ampalagua (Boa constrictor occidentalis) en la República Argentina - A 20 años de su inclusión en el Apéndice I de la CITES. Proyecto CITES No. S-298. Fundación Biodiversidad-Argentina, Buenos Aires. 